\title{
Cytochemical characterization of gill and hepatopancreatic cells of the crab Ucides cordatus (Crustacea, Brachyura) validated by cell metal transport
}

\author{
Priscila Ortega ${ }^{1}$; Rudney A. Santos ${ }^{2}$; Patrícia Lacouth ${ }^{1}$; Enrique E. Rozas ${ }^{1}$; \\ Márcio R. Custódio ${ }^{1} \&$ Flavia Pinheiro Zanotto ${ }^{1}$
}

\begin{abstract}
1. Laboratório de Biologia Celular de Invertebrados Marinhos, Instituto de Biociências, Departamento de Fisiologia, Universidade de São Paulo, Rua do Matão, Travessa 14, 101, São Paulo, 05508-900, SP, Brazil. (priortega218@gmail.com; patricialacouth@gmail.com; isoquir@gmail.com; mcust@usp.br; fzanotto@usp.br)

2. Departamento de Mineralogia e Geotectônica, Instituto de Geociências, Universidade de São Paulo, São Paulo, Brazil. (rudbio@yahoo.com.br)
\end{abstract}

\begin{abstract}
Ucides cordatus (Linnaeus, 1763) is a hypo-hyper-regulating mangrove crab possessing gills for respiratory and osmoregulatory processes, separated in anterior and posterior sections. They also have hepatopancreas, which is responsible for digestion and absorption of nutrients and detoxification of toxic metals. Each of these organs has specific cells that are important for in vitro studies in cell biology, ion and toxic metals transport. In order to study and characterize cells from gills and hepatopancreas, both were separated using a Sucrose Gradient (SG) from 10 to $40 \%$ and cells in each gradient were characterized using the vital mitochondrial dye DASPEI (2-(4-dimethylaminostyryl)-N- ethylpyridinium iodide) and Trichrome Mallory's stain. Both in 20 and 40\% SG for gill cells and 30\% SG for hepatopancreatic cells, a greater number of cells were colored with DASPEI, indicating a larger number of mitochondria in these cells. It is concluded that the gill cells present in $20 \%$ and $40 \%$ SG are Thin cells, responsible for respiratory processes and Ionocytes responsible for ion transport, respectively. For hepatopancreatic cells, the $30 \% \mathrm{SG}$ is composed of Fibrillar cells that possess larger number of membrane ion and nutrient transporters. Moreover, the transport of toxic metal cadmium (Cd) by isolated hepatopancreatic cells was performed as a way of following cell physiological integrity after cell separation and to study differences in transport among the cells. All hepatopancreatic cells were able to transport Cd. These findings are the first step for further work on isolated cells of these important exchange epithelia of crabs, using a simple separation method and to further develop successful in vitro cell culture in crabs.
\end{abstract}

KEYWORDS. Mangrove crab, DASPEI, cell cadmium transport, in vitro cells.

\begin{abstract}
RESUMO. Caracterização citoquímica de células de brânquias e hepatopâncreas de Ucides cordatus (Crustacea, Brachyura) validado por transporte celular de metais. Ucides cordatus (Linnaeus, 1763) é um caranguejo de mangue hiper-hipo-regulador que possui brânquias responsáveis por processos respiratórios e osmorregulatórios. Apresentam também hepatopâncreas, que realizam digestão, absorção de nutrientes e detoxificação de metais tóxicos. Cada um desses órgãos possui células específicas que são importantes para estudos in vitro em biologia celular e transporte de íons e metais tóxicos. Visando estudar e caracterizar as células de cada órgão, estas foram separadas em um gradiente de sacarose (SG) de 10 a $40 \%$ e as células de cada gradiente foram caracterizadas usando o marcador de mitocôndria DASPEI (2-(4-dimethylaminostyryl)-N- ethylpyridinium iodide) e o corante Tricromo de Mallory. No SG de 20 e 40\% para células branquiais e 30\% para células hepatopancreáticas, foi observado um maior número de células coradas com DASPEI, indicando um maior número de mitocôndrias nessas células. Conclui-se que células branquiais presentes no SG de 20 e 40\% são "Thin cells", responsáveis por processos respiratórios, e Ionócitos, responsáveis pelo transporte iônico, respectivamente. Para as células hepatopancreáticas, o SG de 30\% é composto de células Fibrilares que possuem um maior número de transportadores de membrana para íons e nutrientes. Adicionalmente, o transporte do metal tóxico cádmio $(\mathrm{Cd})$ em células hepatopancreáticas isoladas foi realizado para testar a integridade fisiológica das células isoladas e estudar o transporte entre os diferentes tipos celulares. Todas as células hepatopancreáticas transportaram Cd. Os resultados obtidos são um primeiro passo para trabalhos adicionais em células isoladas de importantes epitélios de troca em caranguejos, utilizando um método de separação simples e visando futuros estudos com cultura de células em caranguejos.
\end{abstract}

PALAVRAS-CHAVE. Caranguejo-do-mangue, marcador de mitocôndria DASPEI, transporte celular de cádmio, células in vitro.

The crustacean gills, apart from gas exchange, are responsible for other functions such as acid basic balance, ammonia excretion, ionic exchange and osmoregulation (GeNOvese et al., 2000; Freire et al., 2008). To perform these processes, specific cells for each function are found: (1) Pillar cells that are important in gill support; (2) Thick or Ionocytes cells that perform osmoregulation and ionic exchange; (3) Thin cells that are important for respiration and (4) Haemocytes, responsible for coagulation and encapsulation of toxics agents in the organism (LAWSON et al., 1995; Freire et al., 2008; Ortega et al., 2011).

The hepatopancreas of crustaceans, on the other hand, play a role in absorption and nutrient storage, digestive enzyme synthesis, detoxification of xenobiotics and calcium balance (Lyon \& Simkiss, 1984; Chavez-Crooker et al., 2001; Zilli et al., 2003; PAganini \& Bianchini, 2009;
STERLING et al., 2010). There are four cell types responsible for these functions: 1. Embryonic (E) cells, which originate the other cell types; 2. and 3. Resorptive (R) and Fibrillar (F) cells, important for absorption of nutrients; and 4. Blister (B) cells, responsible for digestion and storage of nutrients (Vogt, 1994; Chavez-Crooker et al., 2001; Verri et al., 2001; Fiandra et al., 2006; ORTEga et al., 2011; Овг et al., 2011).

Several aspects of the physiology of these cell types remain poorly known, due to the complex structures and cellular interactions as well as to the relatively unsuccesfull techniques aiming for crustacean cell culture of long term (Mulford \& Villena, 2000). Additionally, few studies intending to separate the different cell types from gills and hepatopancreas were developed in crustaceans. Percollgradient centrifugation was used for lobster hepatopancreas 
cell separation (AHEARN et al., 1983; Nies et al., 1995), and for prawn and crayfish hepatopancreas (see review by Mulford \& Villena, 2000), both aiming to study different aspects of cell biology. As an alternative, stand out the study of Chavez-Crooker et al. (2001), which used a centrifugal elutriation technique to separate the hepatopancreatic cells of lobster Homarus americanus (Milne-Edwards, 1837). This methodology, however, depends on specific centrifuge adapted for that. Later, and for the first time, gill cells were separated on a $30,40,50$, and $80 \%$ sucrose gradient in lobsters (SÁ et al., 2009) and recently, the study of ORTEGA et al. (2011), gill and hepatopancreatic cells of a mangrove crab, Ucides cordatus (Linnaeus, 1763), were isolated using the same technique of sucrose gradient separation $(10-40 \%)$.

ORTEGA et al. (2011), using the sucrose gradient method, was not able to distinguish morphologically two cell types in each organ: hepatopancreatic $\mathrm{F}$ and $\mathrm{R}$ cells in the 20 and $30 \%$ sucrose gradient, and pillar and ionocyte gill cells in the 30 and $40 \%$ sucrose gradient. This is a common difficulty in crustacean cell separation because of similar densities among different cell types, particularly for cells from hepatopancreas (see Mulford \& Villena, 2000).

Classical histological staining techniques may provide an easy and economic way to characterize tissues and cells. Among these techniques, Trichrome Mallory's stain belongs to the commonly used technique in which four dyes, aniline blue, orange $\mathrm{G}$, light green and acid fuchsine are combined (see Wolún-ChOlEwA et al., 2010), to differentiate parts of a tissue or cell components. Moreover, the fluorescent probe DASPEI is a vital mitochondrial dye, selective for the presence of mitochondria. It has been used for the rapid visualization of several distinct classes of epidermal cells in vivo and in vitro (LeISE, 1996). It was also used for recognition of mitochondria present in chloride cells in teleost skin and epidermal electroreceptors, and in gastropod heart endothelial cells (see review by LeISE, 1996).

Therefore, the objective of this work is to characterize gills and hepatopancreatic cells morphologically separated by sucrose gradient using the DASPEI technique and Mallory's triple staining. In addition, to test the physiological viability and differences in transport of a group of cells separated by this technique, cell membrane transport for a toxic metal, cadmium, was tested using a fluorescent probe. Such work will be primordial for future studies on isolated crab cells and metal transport.

\section{MATERIAL AND METHODS}

Animals. The animals (U. cordatus) were collected (IBAMA/SISBIO 18160) in mangrove ecosystems in Itanhaém - SP region and were acclimated at University of São Paulo vivarium in containers with sea water at $20 \%$ salinity using constant aeration and free access to dry environment, with light/dark photoperiod 12:12 hours and environmental temperature of $25 \pm 1{ }^{\circ} \mathrm{C}$. The crabs remained, at least, for one week at these conditions before the experiments started. They were fed with mangrove leaves in alternate days, being suspended before the experiment. A total of 20 animals were used, all males during intermolt.

Gills and hepatopancreatic cells separation. An extraction solution was used $(\mathrm{NaCl} 395 \mathrm{mM} ; \mathrm{KCl} 10 \mathrm{mM}$; $\mathrm{NaHCO}_{3} 2.5 \mathrm{mM}$; $\mathrm{NaH}_{2} \mathrm{PO}_{4} 2.5 \mathrm{mM}$; Hepes $3.75 \mathrm{mM}$; Glucose $1 \mathrm{mM}$; EDTA $0.9 \mathrm{mM}, \mathrm{pH} 7.8$ ) and $200 \mu \mathrm{L}$ of Trypsin at $0.5 \%$ was added in a proportion of $2: 1$ (volume/ tissue mass). The gills were kept in this solution in ice, immersed during 15 minutes. They were then chopped with scissors for 15 minutes and stirred in bath at $25^{\circ} \mathrm{C}$ for 15 minutes at $1.8 \mathrm{x} \mathrm{g}$. After, the gills were filtered in $30 \mu \mathrm{m}$ fine mesh and centrifuged for 5 minutes, at $115 \mathrm{xg}$ at $4^{\circ} \mathrm{C}$. After this procedure, a portion of the cells that sedimented (pellet) were separated in the extraction solution and kept in ice. The final volume of suspended cell was $1 \mathrm{~mL}$.

For hepatopancreatic cells, we used ORTEGA et al. (2011) method, where cell dissociation was performed using a magnetic stirring. The hepatopancreas was added to a beaker with $15 \mathrm{~mL}$ of extraction solution and stirred for 30 minutes, using a proportion of 2:1 (volume/tissue mass). Then, the solution was filtered in $30 \mu \mathrm{m}$ mash and taken to the centrifugation for 5 minutes, $115 \mathrm{x} \mathrm{g}$, and stored for separation in the sucrose gradient (SG). The final volume of suspended cell was $2 \mathrm{~mL}$.

Sucrose gradient. According to ORTEGa et al. (2011), sucrose concentrations of $10,20,30$ and $40 \%$, were dissolved in saline solution. Next, $2 \mathrm{~mL}$ of each sucrose concentration was added carefully, forming a density gradient. After this, the gills/hepatopancreatic cells were centrifuged at $7 \mathrm{x} \mathrm{g}$ for 3 minutes/ $115 \mathrm{x}$ g for 5 minutes, respectively. Next, the layers with cells were aspirated with Pasteur pipet and kept in ice.

Cell characterization. Each cell fraction obtained in the sucrose gradient was counted using a Neubauer chamber adjusted to $4 \times 10^{4} \mathrm{cell} / \mathrm{mL}^{-1}$. The slides were prepared using a cytocentrifuge $(100 \mu \mathrm{l}$ per spot $-80 \mathrm{x}$ g / 5 min - Cytospin 248, Fanem). The cells were fixed with formaldehyde sublimate for $30 \mathrm{~min}$, stained with Mallory's Trichrome following usual methods (Martoja and Martoja, 1967) and mounted with Entellan (Merck). For DASPEI the cell suspension was incubated with $2 \mu \mathrm{g} /$ $\mathrm{ml}$ of DASPEI during 1 hour at room temperature. Next, the cytospins were prepared as described and observed in a fluorescence microscope (Zeiss) at $461 \mathrm{~nm}$ and $560 \mathrm{~nm}$.

Cellular transport. The hepatopancreatic cells previously dissociated were labeled with Fluo-3 AM $(28 \mu \mathrm{M})$ during 1 hour in shaker at $110 \mathrm{rpm}$ at room temperature. After, the cells were centrifuged at $405 \mathrm{x} \mathrm{g}$ for 5 minutes to separate from the Fluo-3 solution and then washed in the transport solution, similar to the extraction solution, but without EDTA. In the Spectrofluorimeter (Biotek), fluorescence change was measured at an emission of $525 \mathrm{~nm}$ and excitation of $495 \mathrm{~nm}$. The cellular transport was measured for 90 seconds in real time. In an ELISA 
plate, $180 \mu \mathrm{L}$ of cells were added with $\mathrm{CdCl}_{2}$ concentrations at final concentration of $0.5,1.0$ and $1.5 \mu \mathrm{M}$. The variation in fluorescence $(\Delta \mathrm{F})$ was measured for each concentration of $\mathrm{Cd}$.

For cellular viability it was used the Trypan Blue method where $20 \mu \mathrm{L}$ of Trypan Blue were added to $200 \mu \mathrm{L}$ of cells (Tennant, 1964) and put in a Neubauer chamber. The viability was quantified by the visualization of the stained cells (unviable) and translucent cells (viable) in four quadrants. For all experiments, it was used $23 \times 10^{4}$ cells consistently.

Statistical analysis. We calculated the average percentage of stained and unstained cells with DASPEI and Triple Mallory. The graphs were prepared using Sigma Plot program and the statistical analysis was executed using Sigma Stat 3.1 program, through One-way ANOVA. Normality and homogeneity of variance was tested through Bartlett Test. For Cd transport, we measured the transport among different $\mathrm{Cd}$ concentrations using Repeated Measures ANOVA. Whenever the data did not follow normality or equality of variances, a Friedman Repeated Measures ANOVA on ranks was performed.

\section{RESULTS}

Gills. It was observed that gill cells colored with DASPEI were mainly present in 20 and $40 \%$ sucrose gradient (ANOVA, ${ }^{*} \mathrm{P}<0.05$ and $* * \mathrm{P}<0.001$, respectively; Figs 1-4, 9, 10; Tab. I). Next, the cells were analyzed using Triple Mallory staining technique. This approach allows the observation of cells protein compounds, where the affinity for fuchsine and orange $G$, represent proteins associated with intense activity areas, such as chromatin, nuclei and basophilic cytoplasm, while the Methyl blue/ light green represent support proteins (Labiocel, 2002; Tab. III, Figs 1-4).

In $20 \%$ SG, most cells were small, with a central nuclei and a weakly acidophilous cytoplasm without inclusions. In $40 \% \mathrm{SG}$, large part of the cells were stained with Methyl blue (Figs 1-4). Moreover, cells present in the 10 and $30 \%$ sucrose gradient were not colored by DASPEI (ANOVA, ${ }^{*} \mathrm{P}<0.05$; Figs $1-4,12$ ). Gill cells in $10 \% \mathrm{SG}$, presented a strong acidophilous character. $30 \% \mathrm{SG}$ cells presented orange $\mathrm{G}$ affinity, and a few percent of the cells (19\%) presented no coloration (Figs 1-4).

Hepatopancreas. All cells colored with DASPEI were located in the $30 \%$ sucrose gradient $\left({ }^{*} \mathrm{P}<0.05\right.$; Figs 5-8, 11; Tab. II). On the other hand, for 10, 20 and $40 \%$ sucrose gradient, most cells were not colored with DASPEI, and the results were significant (ANOVA $* \mathrm{P}<0.05$; Figs $5-8,11)$.

Results with Triple Mallory, showed the presence of cells with a secretory role and with proteins in its interior (Labiocel, 2002), which are E cells found 10\% SG and colored with Orange G (Figs 5-8). For F and R cells both were weakly acidophilous as shown by the low affinity for fuchsine, suggesting the presence of proteins in its interior. $B$ cells were colored in methyl blue and orange $G$, indicating intense RNA synthesis as well as the presence of proteins for cell support (LABIOCEL 2002, Figs 5-8; Tab. IV).
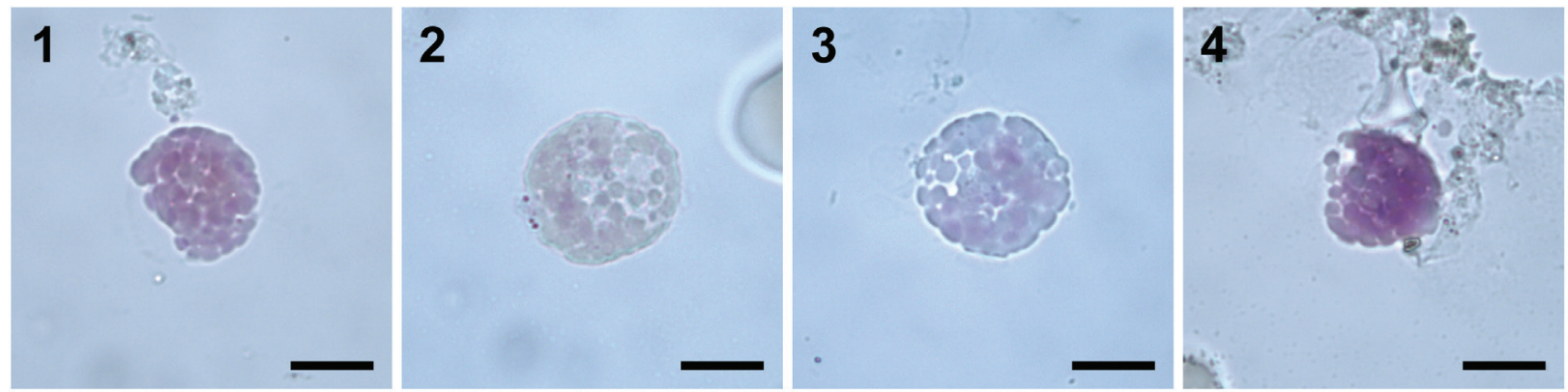

Figs 1-4. Gill cell types of the mangrove crab Ucides cordatus (Linnaeus, 1763) colored with Triple Mallory. 1, Haemocytes cells present in the 10\% SG; 2 , Thin cells present in the $20 \%$ SG; 3, Pillar cells present in the $30 \%$ SG; 4, Ionocytes or thick cells present in the $40 \%$ SG. Scale Bar $10 \mu$ m
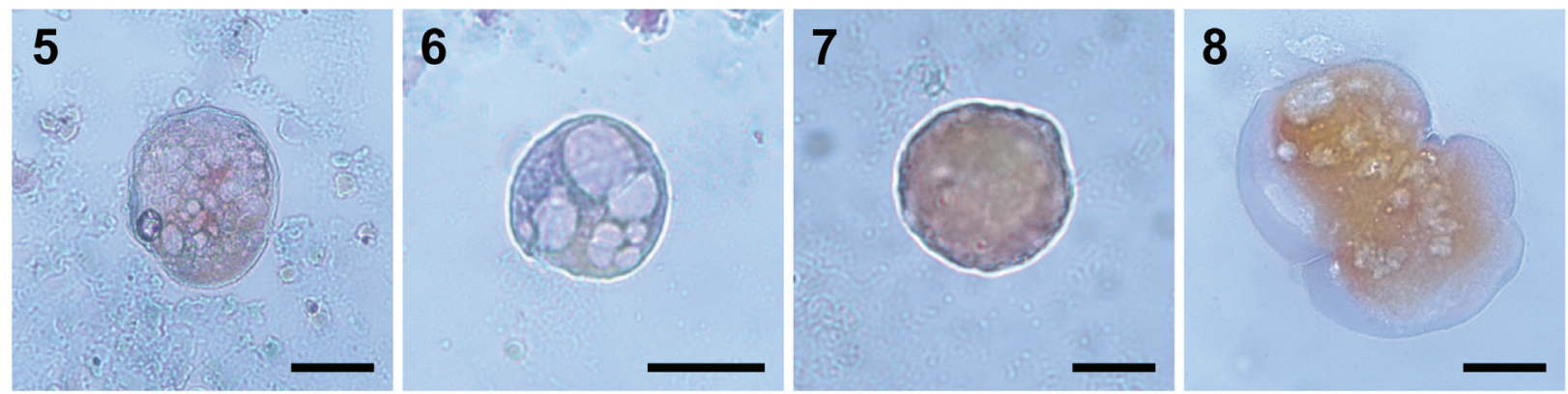

Figs 5-8. Hepatopancreatic cells types of the mangrove crab Ucides cordatus (Linnaeus, 1763) colored with Triple Mallory. 5, E cells present in the $10 \%$ SG; 6, F cells present in the $20 \%$ SG; 7, R cells present in the $30 \% \mathrm{SG} ; 8$, B cells present in the $40 \% \mathrm{SG}$. Scale Bar $10 \mu \mathrm{m}$ 
Tab. I. Percent (mean \pm se) of the gills cells of the mangrove crab Ucides cordatus (Linnaeus, 1763), separated in each sucrose gradient (\%).

\begin{tabular}{ccc}
\hline $\begin{array}{c}\text { Sucrose gradient } \\
(\%)\end{array}$ & Cell type & Means \pm se $(\%)$ \\
\hline 10 & Haemocytes & $80.3 \pm 7.5$ \\
20 & Thin cells & $82.6 \pm 5.0$ \\
30 & Pillar cells & $76.3 \pm 2.7$ \\
40 & Thick or ionocyte cells & $86.3 \pm 7.2$ \\
\hline
\end{tabular}

Tab. II. Percent (mean \pm se) of hepatopancreatic cells of the mangrove crab Ucides cordatus (Linnaeus, 1763), separated in each sucrose gradient (\%).

\begin{tabular}{ccc}
\hline Sucrose gradient $(\%)$ & Cell type & Means \pm se $(\%)$ \\
\hline 10 & E cells & $76.6 \pm 9.3$ \\
20 & R cells & $77.0 \pm 4.1$ \\
30 & F cells & $77.6 \pm 7.0$ \\
40 & B cells & $72.3 \pm 7.7$ \\
\hline
\end{tabular}

Cadmium transport in hepatopancreas. Figure 14 shows Cd transport in four different hepatopancreatic cells. It is possible to see that $\mathrm{R}$ cells transported $\mathrm{Cd}$, measured as fluorescence units, in higher amounts than E cells, followed by B cells. The difference, however, was not significant (ANOVA, $\mathrm{P}>0.05$ ). In relation to differences among $\mathrm{Cd}$

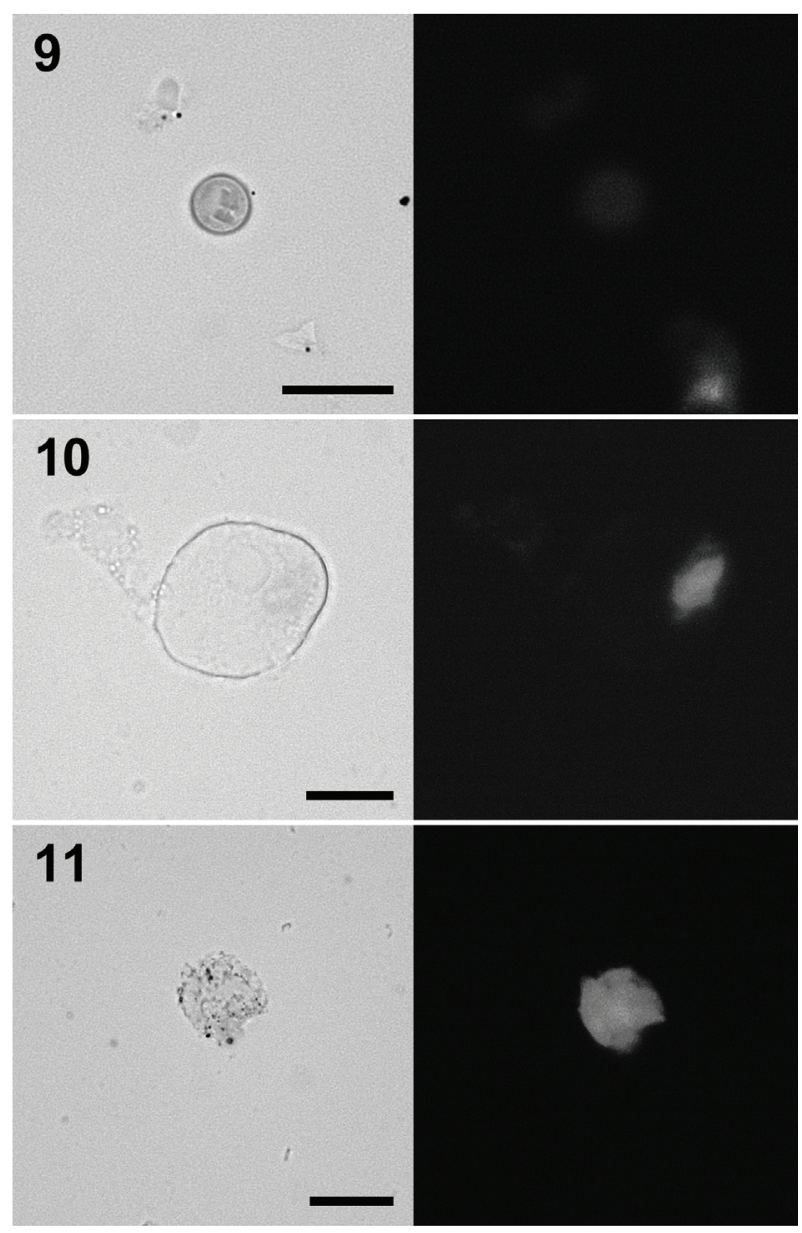

Figs 9-11. Gills cells of the mangrove crab Ucides cordatus (Linnaeus, 1763) colored with DASPEI. 9, Thin cells present in the $20 \%$ SG, paired with thin cells colored with DASPEI; 10, Ionocytes or thick cells present in the $40 \%$ SG paired with ionocytes colored with DASPEI. Hepatopancreatic cells colored with DASPEI. 11, F cells present in the $30 \%$ SG paired with F cells colored with DASPEI. Scale Bar $10 \mu \mathrm{m}$ concentrations, it was seen that B cells transported more $\mathrm{Cd}$ at $1.5 \mu \mathrm{M}$ than $\mathrm{Cd}$ at $0.5 \mu \mathrm{M}$ (ANOVA Repeated Measures, $\mathrm{P}<0.05)$. For F cells, Cd at $1.5 \mu \mathrm{M}$ was transported in higher amounts than $\mathrm{Cd}$ at 1.0 and $0.5 \mu \mathrm{M}$ (Friedman Repeated Measures ANOVA on ranks, $\mathrm{P}<0.05)$. For the other cells, $\mathrm{R}$ and $\mathrm{E}$, there were no difference in transport values among the three concentrations of $\mathrm{Cd}$.

\section{DISCUSSION}

The sucrose gradient separation was efficient, simple and effective (ORTEGA et al., 2011), and in addition we could verify here by cytochemical characterization that the separation method consistently resulted in one cell type for each sucrose fraction. For gill cells, purity of one cell type varied from $76-87 \%$ and for hepatopancreatic cells from $72-78 \%$ (see Tabs I and II). Additionally, the physiological viability and membrane integrity of the separated hepatopancreatic cells was tested through the use of a fluorescent dye for cadmium (Fluo 3 AM). We observed different transport rates for different cell types. The transport was very rapid, within $1 \mathrm{~s}$ of exposure and decreased rapidly, lasting for 5 seconds after the initial transport peak. Therefore, we demonstrated and characterized different cell types from important exchange epithelia of a mangrove crab and tested the physiological integrity of the cell's membrane through transport process studies.

Gill cells. A separation between respiratory and osmoregulatory cells can be inferred by the larger presence of mitochondria, as shown by DASPEI fluorescence for

Tab. III. Percent of the gills cells of the mangrove crab Ucides cordatus (Linnaeus, 1763), separated in sucrose gradient (SG), stained with Triple Mallory.

\begin{tabular}{lccccc}
\hline \multicolumn{5}{c}{ Gills Cells (\%) } \\
\hline & \multicolumn{5}{c}{ Triple Mallory Technique } \\
\hline & \multicolumn{7}{c}{ Proteins associated with } & Support Proteins \\
\cline { 2 - 6 } SG/Cell type & Yellow/ & Light & Dark & Blue & Without \\
& Orange & Pink & Pink & & Color \\
$10 \%$ / Hemocyte & 0 & 11 & 85 & 4 & 0 \\
$20 \% /$ Thin cells & 0 & 71 & 23 & 6 & 0 \\
$30 \% /$ Pillar cells & 56 & 25 & 0 & 0 & 19 \\
$40 \% /$ Ionocytes & 2 & 5 & 35 & 58 & 0 \\
\hline
\end{tabular}

Table IV. Percent of hepatopancreatic cells of the mangrove crab Ucides cordatus (Linnaeus, 1763), separated in sucrose gradient (SG), colored with Triple Mallory.

\begin{tabular}{lccccc}
\hline \multicolumn{5}{c}{ Hepatopancreatic Cells (\%) } \\
\hline & \multicolumn{5}{c}{ Triple Mallory Technique } \\
\cline { 2 - 6 } & \multicolumn{6}{c}{ Proteins associated with } & Support Proteins \\
\cline { 2 - 6 } intense activity areas & Withe & Without \\
Yellow/ & Light & Dark & Color \\
$10 \%$ / E cells type & Orange & Pink & Pink & & 0 \\
$20 \%$ / R cells & 60 & 0 & 27 & 13 & 0 \\
$30 \%$ / F cells & 6 & 20 & 71 & 2 & 0 \\
$40 \%$ / B cells & 33 & 65 & 12 & 7 & 0 \\
\hline
\end{tabular}




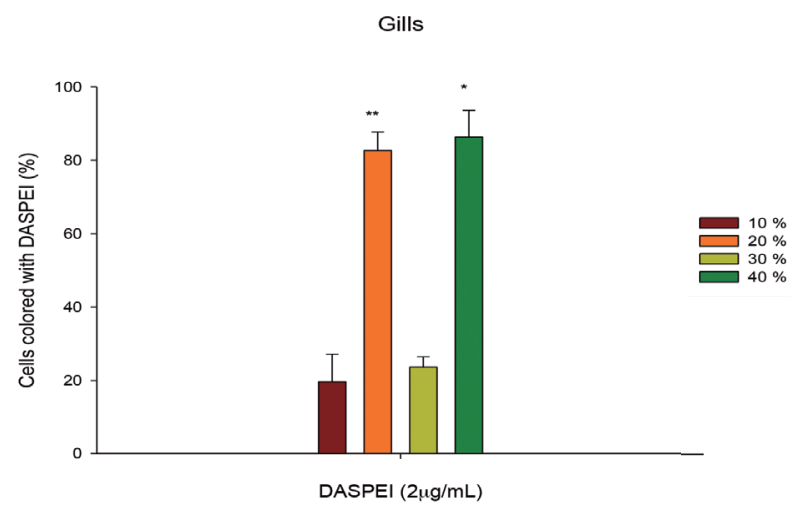

Fig. 12. Percent (mean \pm s.e) of the gills cells of the mangrove crab Ucides cordatus (Linnaeus, 1763) colored with DASPEI $(* \mathrm{P}<0.05 ; * * \mathrm{P}<0.001)$. $10,20,30$ and $40 \%$ represent the four different sucrose gradients.

Hepatopancreas

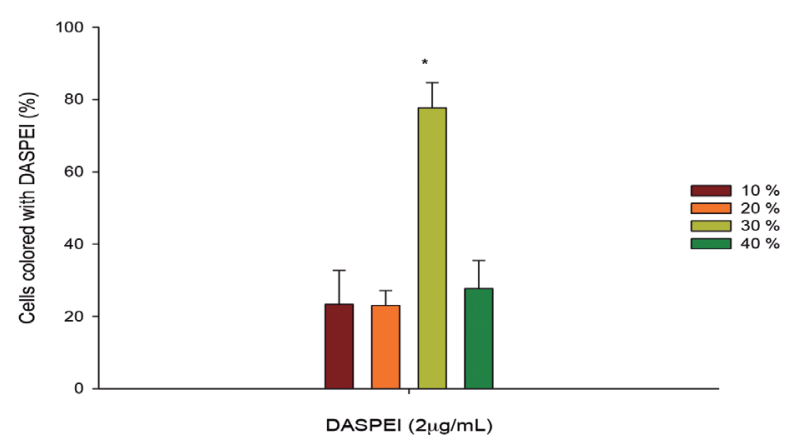

Fig. 13. Percent (mean \pm s.e) of the hepatopancreatic cells of the mangrove crab Ucides cordatus (Linnaeus, 1763) colored with DASPEI $(* \mathrm{P}<0.05)$. $10,20,30$ and $40 \%$ represent the four different sucrose gradients.

each cell type. We found more mitochondria in the $20 \%$ (Thin cells) and 40\% (Thick or Ionocyte cells) sucrose layers (FrEIRE et al., 2008). Both cell types are respiratory and osmoregulatory in nature (MARTINEZ et al., 1999; ORTEGA et al., 2011).

In gills, the $10 \% \mathrm{SG}$ was mostly composed of haemocytes (ORTEGA et al., 2011). These cells are found in the hemolymph space or in the intracellular septum of the gill, involved in coagulation, encapsulation and phagocytosis. These cells can also exert an antibacterial activity, as shown by a study developed by ScHNAPP et al. (1996). Furthermore, they are divided in granular or agranular. The granular cells are involved in the oxidation system, while the agranular cells participate in hemolymph coagulation (Rodriguez et al., 1995). The haemocytes presented a strong affinity for the acid fuchsine in the Triple Mallory treatment, indicating the presence of peptides or peptide precursors (LABIOCEL, 2002). The lack of DASPEI fluorescence is in agreement with the observation that the haemocytes do not have a large number of detectable mitochondria in its interior (LEISE, 1996).

In the $20 \% \mathrm{SG}$ it was observed the predominance of thin cells (ORTEGA et al., 2011). These cells are found in the respiratory epithelium. They presented granules inside, mostly mitochondria, playing a role in respiration (Freire et al., 2008; OrTEGA et al., 2011). We confirmed that by strong coloring with DASPEI and weak fuchsine staining in the Triple Mallory treatment. Therefore, we can conclude that the cells in the $20 \%$ SG are thin cells and they have large number of mitochondria and a basophilic cytoplasm, playing a role in the respiratory process (LEISE, 1996; LABIOCEL, 2002).

In the $30 \%$ SG we observed pillars cells. These cells are multinucleated, shaped "watch glass", constituted by microtubules and desmossomes in the basal surface and perpendicular grooves in the apical side. The system of developed microtubules integrates the dimensions of the hemocel and gives structural stability to the lamellae (MARTinez et al., 1999). These cells are responsible for the intralamelar septum sustentation and define the hemolymph flow routes (MARTinez et al., 1999) and also limit the hemolymphatic space deformation during changes in the hydrostatic pressure (KIKUCHI \& SHIRAISHI, 1997). With the techniques involved in this study, the pillars cells did not show fluorescence with DASPEI, therefore possessing small number of mitochondria. On the other hand, we could verify the presence of proteins inside these cells (fuchsine/orange G staining), usually found in secretory cells (LABIOCEL, 2002; WoLÚN-ChOLEWA et al., 2010). Therefore, these cells are not involved with respiration or ionic transport, because of the imperceptible presence of mitochondria in its interior (LEISE, 1996). On the other hand, in a study developed by GeNOvese et al., 2000 and FREIRE et al. (2007), there is a suggestion that pillars cells can help in ionic transport besides the respiration process.

The $40 \%$ SG presents the thick or ionocytes cells. These cells, located in the posterior gill, have sphericalcubic nucleus, interdigitations in the plasma membrane related to the presence of mitochondria and are involved in the process of transport through the gill epithelium (Martinez et al., 1999; Genovese et al., 2000; Freire et al., 2008; OrTEgA et al. 2011). Our results showed that these cells present a large number of mitochondria, showing fluorescence with DASPEI, therefore confirming their role in ionic transport and osmoregulation (LEISE, 1996). It was observed that these cells stained with Methyl blue and fuchsine in the Triple Mallory technique, noting the presence of increased synthesis of RNA in the nuclei and also proteins for support, respectively (LABIOCEL, 2002; Wolún-CholewA et al., 2010).

Hepatopancreatic cells. In relation to hepatopancreatic cells, the $10 \%$ SG is composed mostly of E cells (OrTEGA et al., 2011). With DASPEI probe, there was no fluorescence, indicating a small number of mitochondria, corroborating the studies realized by VOGT (1994). Results with Triple Mallory showed the presence of a secretory cell type with proteins in its interior (LABIOCEL, 2002). These cells have a big nucleus, with few cellular organelles and are responsible for originating other cell types (Vogt, 1994; Chavez-Crooker et al., 2001). The endoplasmic reticulum and Golgi are small, with some 

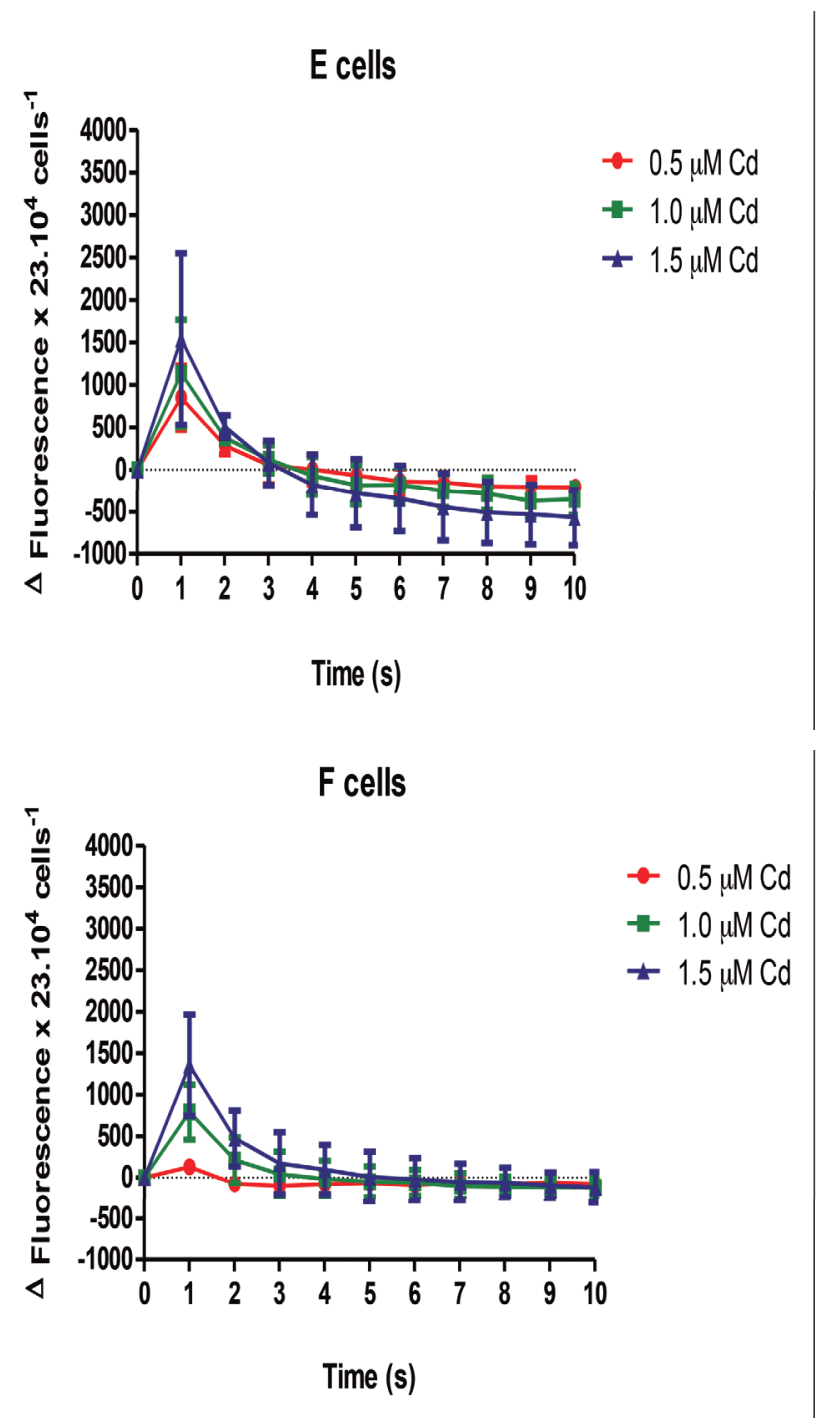
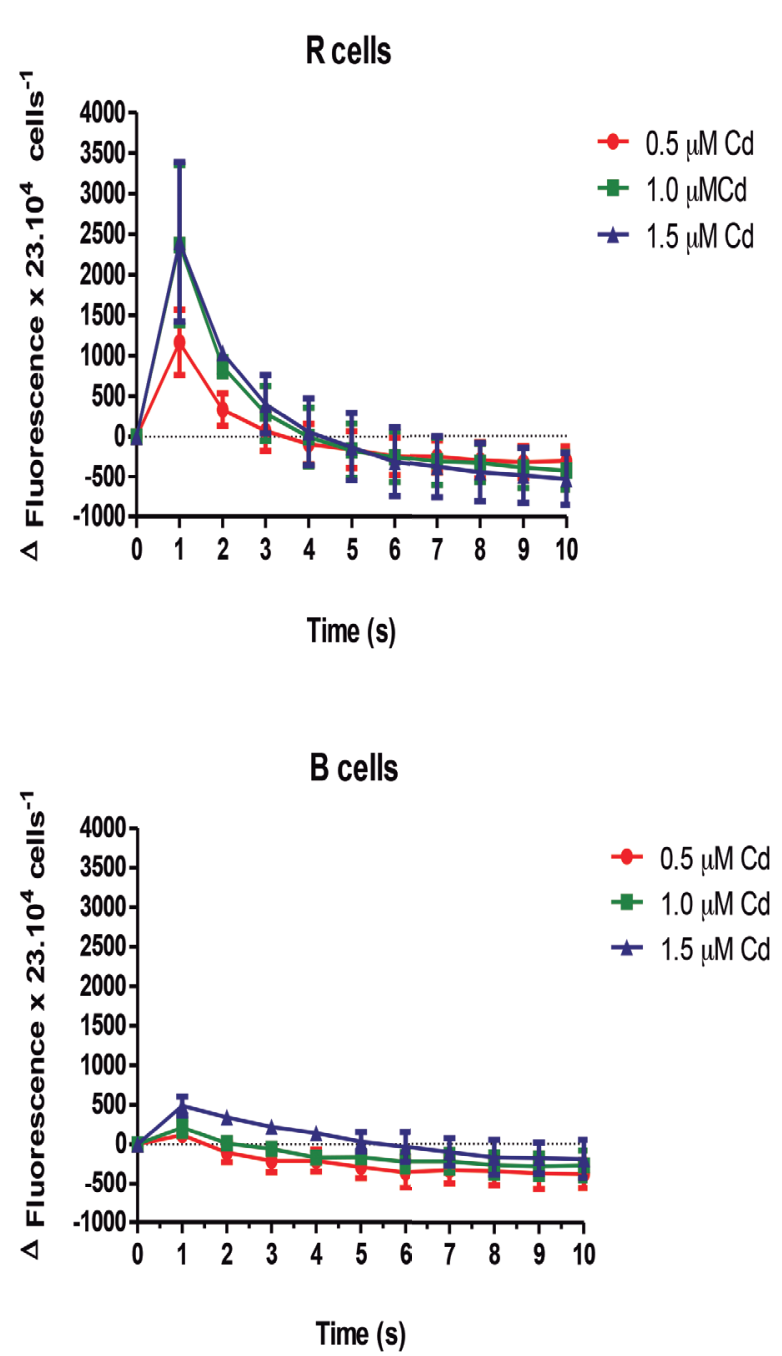

Fig. 14. Cadmium $(\mathrm{Cd})$ transport in four hepatopancreatic cell types of Ucides cordatus (Linnaeus, 1763) represented as fluorescence change ( $\Delta \mathrm{F} \mathrm{X}$ $\left.23.10^{4} \mathrm{cel}^{-1}\right)$ in relation to time (sec.) for different $\mathrm{CdCl}_{2}$ concentrations $(0.5,1.0$ and $1.5 \mu \mathrm{M})$. $\mathrm{N}=3$ or 4 . Embryonic $(\mathrm{E})$ cells; Resorptive $(\mathrm{R})$ cells; Fibrillar (F) cells and Blister (B) cells, present in the 10, 20, 30 and 40\% respectively.

vesicles and cisterns, and the lysossomal system includes primary lysosome and large autophagosomes localized in the supranuclear region. It contains small lipids or glycogen particles. In mitosis, it can influence the neighbor cells differentiation, forming $\mathrm{R}$ cells mainly, from the Golgi vesicles base (VoGT, 1994).

The $20 \% \mathrm{SG}$ is composed of $\mathrm{R}$ cells. The cells were weakly acidophilous and did not show fluorescence with DASPEI probe, also indicating few mitochondria (LEISE, 1996). These cells possess three polarization zones: the apical area with microvilli, tubules of endoplasmic reticulum and mitochondria; the medial area with nucleus, nutrient reserve and some cellular organelles; and the basal area dominated by tubules systems like the smooth endoplasmic reticulum (Vogt, 1994; CHAVEZ-CROOKER et al., 2001).

The F cells are present in the $30 \%$ SG, playing a role in digestive enzyme synthesis. In the presence of
DASPEI, these cells were fluorescent in concentrated areas, indicating the presence of a large number of mitochondria in its interior corroborating with a transport function (LEISE, 1996). They also perform detoxification for certain metals like iron, stored in supranuclear vacuoles (VoGT, 1994). They are characterized by a large number of endoplasmic reticulum and cytoplasmic granules (CHAVEz-CROOKER et al., 2001). They also have a Golgi system presenting big dilated cisterns, organelles distributed homogeneously and the presence of digestive enzymes (VogT, 1994). In Triple Mallory, the cells presented low affinity to fuchsine, indicating the reduced presence of proteins (LABIOCEL, 2002). Our results showed mitochondria localized in concentrated areas of the cell. These cells have the lumen surface well organized, with elongated microvilli. It performs intestinal and hepatic functions, including absorption of small molecules, transport through cell apical membrane and nutrient catalysis, metabolic delivery to 
other organs, reserve storage during the moult period, reproduction and estivation, and detoxification of heavy metals (Vogt, 1994).

The 40\% SG was composed of B cells (OrTEGa et al., 2011). Using DASPEI, the cells did not present any fluorescence, indicating the presence of few mitochondria and, consequently, low use of energetic processes (LEISE, 1996). With Mallory's Trichrome, the cells stained both with Orange G and with Methyl Blue, indicating intense RNA synthesis and the presence of proteins related to support, respectively (LABIOCEL, 2002). They form an apical complex with channels and endocitotic vesicles, small and dense Golgi vesicles, subapicals vacuoles and microtubules (Vogt, 1994). They have also lysosomes and a simple and large intracellular vacuole occupying most part of the cellular compartment (CHAVEZ-CROOKER et al., 2001).

Cadmiun transport in hepatopancreatic cells. Toxic metals are known to accumulate in crustacean cells as precipitated granules, bound to intracellular proteins, such as metalothioneins or transported to a variety of organelles inside the cell (Vogt \& Quinitio, 1994; Ahearn, et al., 2004). Cadmium is a non-essential metal and it is known to enter mammalian cells through calcium $(\mathrm{Ca})$ channels and Divalent Metal Transporters (DMT) (see review by THÉVENOD, 2010) and/or through organic anion exchangers (ENDO et al., 1999). Our results show that Cd enters the isolated hepatopancreatic cells and rapidly disappear within 5 seconds from the cytoplasm. It is known that once toxic metals enters epithelial cells in crustaceans, they can be transported to mitochondria (CHAVEZ-Crooker et al., 2002), lysossomes (Chavez-Crooker et al., 2003) or be extruded from the cell (see review by AHEARN et al., 2004). Therefore, various mechanisms can act to avoid increase in intracellular level of toxic metals in free ionic form, which represents a danger to the normal activities of a cell.

It is interesting to verify that each cell type in the hepatopancreas transport $\mathrm{Cd}$ in different ways. Hepatopancreas are known as the main detoxifier organ in crustaceans, although information about how hepatopancreatic cells accumulate and transport toxic metals is scarce. There are studies reported with cell copper transport (Vogt \& Quinitio, 1994; Chavez-Crooker et al., 2001), cell Zn transport (SÁ et al., 2009; see review by AHEARn et al., 2004). Cd transport, on the other hand, has not been studied in crab cells, apart from earlier work on mixed gill cells and hepatopancreas (ORTEGa \& ZANOTTO, 2012), which were not separated by sucrose gradient.

It is known that mineralized granules are observed in higher amounts in R cells and these granules are surrounded by endoplasmic reticulum membrane in $U$. cordatus (FARINA et al., 2002). Lyon \& Simkiss (1984) found that B cells do not contain any metal inclusion in hepatopancreas of a crayfish, a freshwater crustacean. They found inclusions mainly in F and R cells. Another work showed that F cells store iron and calcium in the supranuclear vacuole in shrimp (VogT \& QUINITIO, 1994) and higher amounts of Cu granules were found in R cells (Vogt \& Quinitio, 1994), apparently inside lysossomes. Based on these results, we would expect that transport in hepatopancreatic cells should reflect levels of intracellular metals and here we found that both $\mathrm{R}$ and $\mathrm{F}$ cells were transporting more $\mathrm{Cd}$ than the other cell types, although not statistically significant.

A similar study looking at hepatopancreatic cells and copper transport reported that all types of cells transport $\mathrm{Cu}$ (ChAvez-Crooker et al., 2003). However, E cells contained the highest $\mathrm{Cu}$ concentration among them. These cells give rise to the other cell types and we would not expect to see higher accumulation rates for younger cells compared to more mature cells. F cells, on the other hand, were shown to have a Na dependent sugar transport (VERRI et al., 2001), unlike the other cells types, as well as L-proline transport (FIANDRA et al., 2006), showing that the main role of these cells is transcellular nutrient transport. However, nutrient transport, such as aminoacid or sugar, does not necessarily parallels transport of ions and the question remains as whether $\mathrm{F}$ cells also transport more toxic metal compared to the other cells.

We separated and characterized cells from two important exchange epithelia of crabs, gills and hepatopancreas, using a simple and efficient method based on cell density separation. Moreover, the viability of the isolated hepatopancreatic cells was tested through the study of a toxic metal transport, $\mathrm{Cd}$, using a fluorescent dye. Studies involving cell separation in crustaceans and, as a further step, to be able to develop cell culture in this group, is primordial. The production of standardized in vitro cell separation is especially important in areas such as cellular biochemistry and toxicology, the focus of future work.

Acknowledgements. We thank Bruno César R. Ramos of the Pigmentation Comparative Physiology laboratory (USP) for the provision of laboratory facilities and technical support. A FAPESP grant (2009/15546-3) and a CNPq scholarship (150240/2012-0) to FPZ supported the research.

\section{REFERENCES}

Ahearn, G. A.; Mandal P. K. \& Mandal, A. 2004. Mechanisms of heavy-metal sequestration and detoxification in crustaceans: a review. Journal of Comparative Physiology B 174:439-452.

Ahearn, G. A.; Monckton, E. A.; Henry, A. E. \& Botfield, M. C. 1983. Alanine transport by lobster hepatopancreatic cell suspensions. American Journal of Physiology 244(2):R150-162.

Chavez-Crooker, P.; Garrido, N. \& Ahearn, G. A. 2001. Copper transport by lobster hepatopancreatic epithelial cells separated by centrifugal elutriation: measurements with the fluorescent dye Phen Green. Journal of Experimental Biology 204:1433-1444.

2002. Copper transport by lobster (Homarus americanus) hepatopancreatic mitochondria. Journal of Experimental Biology 205:405-413.

Chavez-Crooker, P.; Pozo, P.; Castro, H.; Dice, M. S.; Boutet, I.; TAnguY, A.; Moraga, D. \& Ahearn, G.A. 2003. Cellular localization of calcium, heavy metals, and metallothionein in lobster (Homarus americanus) hepatopancreas. Comparative Biochemistry and Physiology C 136:213-224.

Endo, T.; Kimura, O. \& SaKata, M. 1999. Further analysis of cadmium uptake from apical membrane of LLC-PK1 cells via inorganic anion exchanger. Pharmacology and Toxicology 84:187-192. 
Farina, M.; Allodi, S. \& CoRrea, J. D. 2002. Cytoarchitectural features of Ucides cordatus (Crustacea Decapoda) hepatopancreas : structure and elemental composition of electron-dense granules. Tissue and Cell 34(5):315-325.

Fiandra, L; Mandal,P. K.; Giordana, B. \& Ahearn, G. A. 2006. L-Proline Transport by Purified Cell Types of Lobster Hepatopancreas. Journal of Experimental Zoology 305A:851-861.

Freire, C. A.; OnKen, H. \& McNamara, J. C. 2008. A structure function analysis of ion transport in crustacean gills and excretory organs. Comparative Biochemistry and Physiology A 151(3):272-304.

Genovese, G.; Luquet, C. M.; Paz, D. A.; Rosa, G. A. \& Pellerano, G. N. 2000. The morphometric changes in the gills of the estuarine crab Chasmagnathus granulatus under hyper and hyporegulation conditions are not caused by proliferation of specialized cells. Journal of Anatomy 197:239-246.

KIKUCHI, S. \& SHIRAISHI, K. 1997. Ultrastructure and ion permeability of the two types of epithelial cell arranged alternately in the gill of the fresh water branchiopod Caenestheriella gifuensis (Crustacea). Zoomorphology 117:53-62.

LABIOCEL. 2002. Manual de técnicas em Histologia e Biologia Celular do laboratório de Biologia Celular da Faculdade de Medicina da Universidade de São Paulo. São Paulo, Faculdade de Medicina da USP. Consolidação de procedimentos. 89p.

Lawson, S. L.; Jones, M. B. \& MoATE, R. M. 1995. Effect of copper on the ultrastructure of the gill epithelium of Carcinus maenas (Decapoda: Brachyura). Marine Pollution Bulletin 31:63-72.

Leise, E. M. 1996. Selective retention of the fluorescent dye DASPEI in a larval gastropod mollusk after paraformaldehyde fixation. Microscopy Research Techniques 33(6):496-500.

LyON, R. \& SimKISs, K. 1984. The ultrastructure and metal-containing inclusions of mature cell types in the hepatopancreas of a crayfish. Tissue and Cell 16:805-817.

Martinez, C. B. R.; Alvares, E. P.; Harris, R. R. \& Santos, M. C. F. 1999. A morphological study on posterior gills of the mangrove crab Ucides cordatus. Tissue and Cell 31(3):380-389.

Mulfford, A. L. \& VillenA, A. J. 2000. Cell cultures from crustaceans: shrimps, crabs and crayfish. In: Mothersill, C. \& Austin, B. eds. Aquatic Invertebrate Cell Culture. Berlin, Springer Verlag. p. 63-134.

Nies, A. T.; Kinne, R. K. H.; Kinne-Saffran, E. \& Grieshaber, M. K. 1995. Urate transport in Homarus americanus hepatopancreas: studies on membrane vesicles and R cells. American Journal of Physiology 269:R339-349.

Obi, I.; Wells, A. L.; Ortega, P.; Patel, D.; Farah, L.; Zanotto, F. P. \& AHEARN, G. A. 2011. ${ }^{3} \mathrm{H}-\mathrm{L}-\mathrm{leucine}$ transport by the promiscuous crustacean dipeptide-like cotransporter. Journal of Experimental Zoology A 315:465-475.
Ortega, P.; SÁ, M. G.; Custódio, M. R. \& Zanotto, F. P. 2011. Separation and viability of gill and hepatopancreatic cells of a mangrove crab Ucides cordatus. In Vitro Cellular and Developmental Biology Animal 47:346-349.

Ortega, P. \& Zanotto, F. P. 2012. Cellular Cadmium Transport in Gills and Hepatopancreas of Ucides Cordatus, a Mangrove Crab. In: Sarumatari, K. \& Nishimura, M. eds. Crabs: Anatomy, Habitat and Ecological Significance. New York, Nova Science Publishers. p. $107-122$.

Paganini, C. L. \& Bianchini, A. 2009. Copper accumulation and toxicity in isolated cells from gills and hepatopancreas of the blue crab (Callinectes sapidus). Environmental Toxicolology and Chemistry 28:1200-1205.

Rodriguez, J.; Boulo, V.; Mialhe, E. \& Bachere, E. 1995. Characterization of shrimp haemocytes and plasma components by monoclonal antibodies. Journal of Cell Science 108:1043-1050.

SÁ, M. G.; Ahearn, G. A. \& Zanotto, F. P. 2009. ${ }^{65} \mathrm{Zn}^{2+}$ transport by isolated gill epithelial cells of the American lobster, Homarus americanus. Journal of Comparative Physiology 179:605-615.

Schnapp, D.; Kemp, G. D. \& Smith, V. J. 1996. Purification and characterization of a proline-rich antibacterial peptide, with sequence similarity to bactenecin-7, from the haemocytes of the shore crab, Carcinus maenas. European Journal of Biochemistry 240(3):532539.

Sterling, K. M.; Roggenbeck, B. \& Ahearn, G. A. 2010. Dual control of cytosolic metals by lysosomal transporters in lobster hepatopancreas. Journal of Experimental Biology 213:769-674.

THÉVEnOD, F. 2010. Catch me if you can! Novel aspects of cadmium transport in mammalian cells. Biometals 23:857-875.

Verri, T.; Mandal, A.; Zilli, L.; Bossa, D.; Mandal, P. K.; Ingrosso, L.; Zonno, V.; Vilella, S.; Ahearn, G. A. \& Storelli, C. 2001. D -Glucose transport in decapod crustacean. Comparative Biochemistry and Physiology A 130:585-606.

Vogt, G. 1994. Life-cycle and functional cytology of the hepatopancreatic cells of Astacus astacus (Crustacea, Decapoda). Zoomorphology 114:83-101.

Vogt, G. \& Quinitio, E. T. 1994. Accumulation and excretion of metal granules in the prawn, Penaeus monodon, exposed to water-borne copper, lead, iron and calcium. Aquatic Toxicology 28:223-241.

Wolún-Cholewa, M.; Krzysztof, S.; Miroslaw, A.; Szczerba, A. \& Warchol, J. B. 2010. Trichrome Mallory's stain may indicate differential rates of RNA synthesis in eutopic and ectopic endometrium. Folia Histochemica et Cytobiologica 48(1):148-152.

Zilli, L.; Schiavone, R.; Ingrosso, L.; Marsigliante, S.; Zonno, V.; Storelli, C. \& Vilella, S. 2003. Calcium channels are present in the apical plasma membranes of the hepatopancreatic B-cells of Marsupenaeus japonicus. Journal of Comparative Physiology B 173:661-667. 